Nataša Vampeli Suhadolnik

\title{
Ivan Skušek ml. kot zbirateli kitajskega pohištva
}

\section{Uvod}

Slovenski etnografski muzej hrani bogato zbirko kitajskih predmetov, ki jih je Ivan Skušek ml. (1877-1947) nakupil v svojem skoraj šestletnem bivanju v Pekingu v začetku 20. stoletja (1914-1920). Med temi še posebej pomembno mesto zavzemajo raznovrstni kosi pohištva, ki pričajo o Skuškovem pionirskem odkrivanju elegantnih linij kitajskega pohištva.

Skuškova zbirka pohištva je ena redkih zbirk lesenega pohištva v evro-ameriški zbirateljski kulturi, ki je nastala že v prvih dveh desetletjih 20. stoletja. Leseno pohištvo je namreč večjo mednarodno pozornost doseglo šele v 40. in 50. letih 20. stoletja, ko so začele izhajati prve angleške publikacije. Njihovi avtorji so bili ameriški in evropski akademiki, ki so v 20. in 30. letih živeli v Pekingu in so svoja domovanja opremljali s kitajskim pohištvom. Še večja zbirateljska vnema je opazna po ekonomskem odprtju Kitajske v 80. letih 20. stoletja, rastoč interes pa je viden tudi v vedno višjih prodajnih cenah na dražbah, ki že dosegajo milijonske vsote.

V prispevku se bomo osredotočili na pionirsko vlogo Skuška pri odkrivanju sublimnih linij kitajskega pohištva. Pri tem bomo izhajali iz širše perspektive zbirateljstva $\mathrm{v}$ evro-ameriškem prostoru in kulturne klasifikacije, ki je na piedestal večinoma umeščala predmete iz porcelana in laka, ter poskušali umestiti Skuškovo vlogo v širši evropski diskurz zbirateljskih strategij pohištva. Dotaknili se bomo tudi vprašanja definicije kitajske dediščine, predvsem pa postavili pod vprašaj koncept kitajskega pohištva v oziru različnih nacionalnih percepcij in odnosa evropske periferije do nekdanjih kolonialnih sil.

\section{Historični kontekst zbirateljstva kitajskih predmetov: pozen vstop kitajskega lesenega pohištva na mednarodni umetnostni trg}

Hiter vzpon evropske ekonomske moči v 17. in 18. stoletju je definiral tudi globalni obtok dobrin, s čimer se je vzporedno izoblikovala evrocentrična kolonialna percepcija in prefinjen občutek kulturne različnosti. ${ }^{1}$ Predmeti, uvoženi iz Kitajske, so

1 O nadaljnjem spreminjanju odnosa Evrope do Kitajske v 19. stoletju glej tudi Motoh, 2019, 290-291.

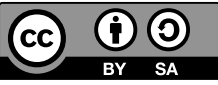

DOI:10.4312/ars.14.2.45-60 
nenadoma izgubili status produkta globalne trgovine ter se znašli v funkciji eksotike, nečesa, kar je bistveno drugačno od ostali izdelkov v Evropi. Skrivnostni in eksotični predmeti iz porcelana, laka in kasneje žada so postali iskan material evropske aristokratske elite ter hkrati novodoben dokaz lastnikove družbene uveljavljenosti. Pridih po eksotiki in obetajoča tržna niša so posledično na Kitajskem že vse od 17. stoletja spodbudili izdelavo izvozne umetnosti, posebej izdelane za evropski trg, ki je ustrezala prefinjenemu estetskemu okusu zahodne noblese. V tem okviru se pojavi tudi izvozno pohištvo, izdelano v eksotičnem laku ter okrašeno v neobičajnih tehnikah, kot sta tehniki kuancai 款彩 (vrezana barva) ali maki-e 蒔絵 (posuta slika). Slednja je bila sposojena iz Japonske, zanjo pa je značilna poslikava $\mathrm{v}$ zlati barvi na črni lakasti podlagi.

Večina teh predmetov je bila torej izdelana posebej za zahodne potrošnike v njim skrivnostnem in zatorej eksotičnem laku in se občutno razlikuje od zloščenega lesenega pohištva za domači trg. Od opijskih vojn naprej se temu mediju sicer pridruži tudi izvozno pohištvo iz elegantno rezljanega lesa hongmu 紅木(črni les), večkrat okrašenega $z$ intarzijami, ki je večinoma prihajalo iz pristaniškega mesta Ningbo v provinci Zhejiang. Kitajsko leseno pohištvo, ki je dolga stoletja krasilo bivalne prostore kitajskih učenjakov, uradnikov in višje elite, pa je vse do začetka 20. stoletja ostalo skrito očem Evropejcev. Trgovski stiki so bili namreč vse do opijskih vojn sredi 19. stoletja skoncentrirani le na južna mesta. Svobodno delovanje tujih trgovcev je bilo precej omejeno, s tem pa tudi možnost neposredne izpostavljenosti elegantno opremljenim studiom kitajske učenjaške in uradniške elite. Poleg tega so prve stike vzpostavili trgovci, ki niso imeli posebnega interesa za lokalno prefinjenost, temveč so predvsem iskali čudesa kitajskega sveta, ki so doma šla za med. Stik z bolj klasičnim notranjim interierjem je bil zatorej v večji meri možen šele po opijskih vojnah, predvsem pa po boksarski vstaji (1899-1901), ko se je prisotnost tujih sil v večji meri usidrala tudi na severu Kitajske.

Ta tržna dinamika doživi svoj odraz tudi v zbirateljski kulturi in formaciji muzejskih pohištvenih zbirk, kjer so do 20. in 30. let prejšnjega stoletja bolj ali manj prevladovali primeri lakiranega pohištva. Metropolitanski muzej umetnosti v New Yorku je na razprodaji zbirke nemškega diplomata Hermana Specka von Sternburga (18521908) leta 1909 odkupil tri kose lakiranega pohištva iz 17. in 18. stoletja (Mason, 1992, 74). Lark E. Mason $(1992,74)$ ugotavlja, da Sternburgova zbirka ni bila edina, ki je dajala prednost lakiranemu pohištvu pred ostalimi oblikami lesenega pohištva, temveč je ta trend opazen tudi v ostalih muzejih, predvsem pa tudi v privatnih zbirkah. Še leta 1922 je Odilon Roche (1868-1947), avtor prve knjige o kitajskem pohištvu v evropskem jeziku, svoje pionirsko delo naslovil Les meubles de la Chine (Kitajsko pohištvo), v katerega je vključil zgolj primere bogato dekoriranega lakiranega pohištva.

Definicija kitajskega pohištva je bila torej v začetku 20. stoletja omejena le na lakirano produkcijo, ki je $\mathrm{z}$ bogato dekoracijo in rezbarijami na dediščini eksotično 
romantičnih okusov značilnega stila chinoiserie navduševala prve evropske zbiratelje (slika 1). Craig Clunas $(1988,102)$ sicer ugotavlja, da je naracija kitajskega pohištva v tem času postopoma že prehajala $v$ sfero bolj enostavnih in plemenitih linij. Tehtnica $v$ to smer pa se je končno prevesila $\mathrm{z}$ izdajo knjige Chinese domestic furniture, ki jo je leta 1944 izdal nemški profesor na univerzi v Pekingu Gustav Ecke (1896-1971). V knjigi je povsem ignoriral lakirano pohištvo in zaključil, da je leseno pohištvo iz trdega lesa edino pravo »kitajsko pohištvo«.

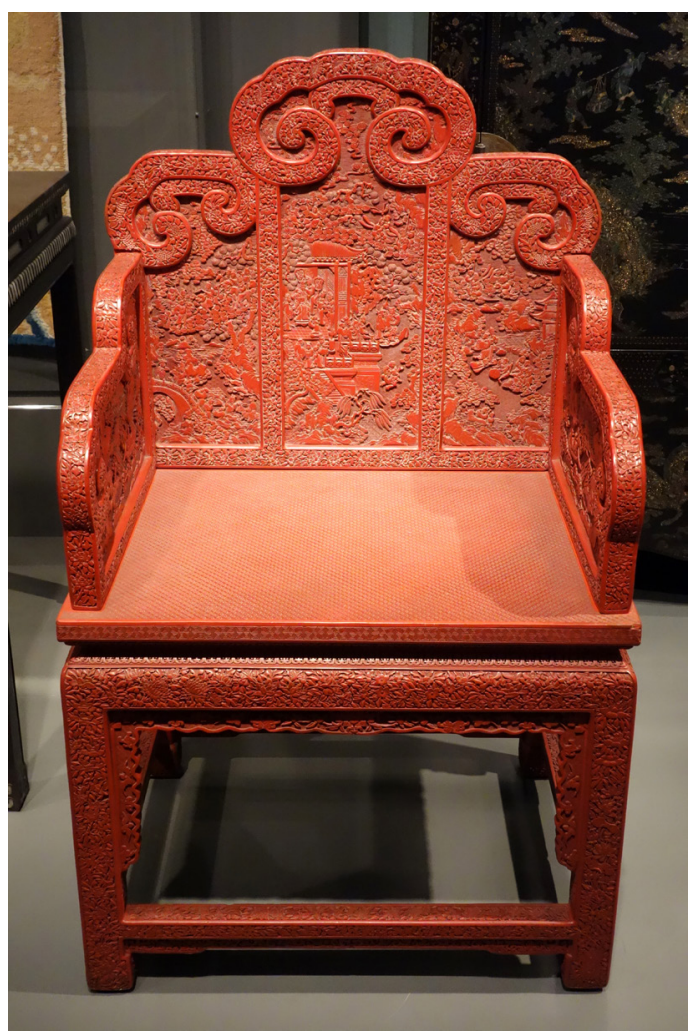

Slika 1: Stol, rezljan lak na lesu, ok. 1750-1850, Kitajska, Asian Art Museum of San Francisco (vir: Wikimedia, javna domena).

Ecke, ki je odraščal v Nemčiji pod vplivom Bauhausa in ostalih modernističnih gibanj ter študiral umetnost, literaturo in filozofijo na različnih nemških univerzah (Handler, 2001, 29), je cenil minimalno dekoracijo, enostavne geometrične oblike, čistost in organskost. To je odkril v prefinjenem in enostavno krašenem pohištvenem stilu vladajoče elite dinastije Ming, izdelanem iz trdega lesa, kar je v naslednjih letih dobilo oznako »klasika«. Eckova knjiga v le 200 izvodih sprva gotovo ni imela širše distribucije, a 
so njegovi pogledi močno odmevali med krogom zahodnih intelektualcev, ki so v 20. in 30. letih živeli v Pekingu. Med njimi še posebej velja omeniti v zahodni umetnosti in zgodovini izobraženega Georgea Katesa (1895-1990), ki se je spomladi leta 1933 ustalil v Pekingu. Sprva je na pekinški jezikovni šoli študiral kitajski jezik, a se je kmalu preselil v tradicionalno kitajsko hišo z osrednjim dvoriščem iz 18. stoletja. Tu se je poistovetil z življenjem kitajskega učenjaka, svoje stanovanje pa opremil z elegantnim pohištvom iz trdega lesa. Njegovo navduševanje nad enostavnim klasičnim slogom lesenega pohištva je leta 1948 vodilo v izdajo knjige Chinese household furniture, ki je nadalje podkrepila primat naravnega lesenega pohištva. Po vrnitvi v ZDA je Kates svoje znanje delil s širšo publiko s številnimi predavanji, članki ter z razstavami pohištva iz lastne zbirke. Istočasno je tudi Ecke, ki je postal profesor na Univerzi Hawaii in kustos na Akademiji umetnosti v Honoluluju, igral ključno vlogo pri utrjevanju vedno večjega zanimanja za kitajsko pohištvo. Tretji protagonist na tej sceni, Laurence Sickman (1906-1988), ki je ravno tako v 30. letih prebival v Pekingu, pa je po povratku v ZDA vzpostavil večjo zbirko kitajskega pohištva $\mathrm{v}$ Nelson-Atkinsonovem muzeju v mestu Kansas (Handler, 2011, 3).

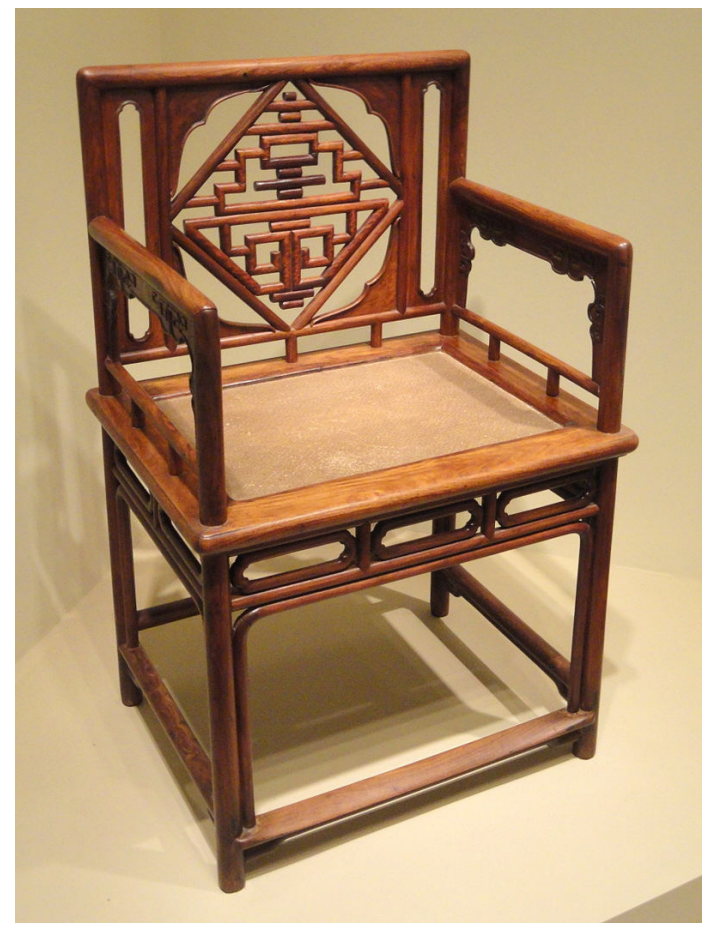

Slika 2: Stol naslonjač, les huang huali, pozno 16-18. st., Kitajska, Arthur M. Sackler Gallery, Washington DC (vir: Wikiwand, javna domena). 
Njihovi kosi pohištva so na nek način formirali predpise, ki so določali kakovost pohištvenih kosov, s tem pa so definirali standardne estetske okuse, na katerih temeljijo tudi prve večje zbirke lesenega pohištva v evro-ameriški regiji. Te so se večinoma formirale šele v povojnem obdobju, s tem pa je tudi klasično pohištvo iz trdega lesa postalo edino pravo kitajsko pohištvo, vredno zbirateljske vneme, študija, poznavalstva in razstav (slika 2). Malo z zamikom je ta percepcija kitajske pohištvene dediščine dobila svoj odmev tudi v Evropi. Muzej V\&A v Londonu je tako leta 1969 pridobil svoj prvi primer pohištva v tem stilu, ki ga je dopolnil s posameznimi nakupi, predvsem pa z zapuščino Johna Addisa (1914-1983), diplomata in zbiratelja, ki je v 50. letih živel v Pekingu (Clunas, 1996, 25).

\section{Problematika kategorizacije kitajskega pohištva in umestitev Skuškovega pohišłva v širši evropski diskurz}

Zahodna retorika je konec 19. in v zgodnjem 20. stoletju »kitajsko pohištvo« enačila $\mathrm{z}$ bogato dekorativnim lakiranim pohištvom, pri tem pa večinoma ignorirala naravno leseno pohištvo. $\mathrm{V}$ dobrih petdesetih letih se retorika na celi črti obrne v nasprotno smer, namesto lakiranega v ospredje pride leseno pohištvo, ki sredi 20. stoletja postane sinonim za pravo »kitajsko pohištvo«. Zasuk iz ene v drugo skrajnost je sicer omiljen v Fergusonovem pregledu kitajske umetnosti, kjer enako pozornost namenja tako lakiranemu kot neokrašenemu lesenemu pohištvu (Ferguson, 1940), a v Pekingu živeči akademiki tehtnico prevesijo na stran minimalistično okrašenega lesenega pohištva.

Problematika kulturne klasifikacije, kategorialnih oznak in materialov, ki so določale percepcije posameznih tipov predmetov in s tem narekovale estetski okus in dinamiko tržne ekonomije, s tem dobi svoj odraz tudi v mediju pohištva. Izključujoči kategoriji lakiranega in klasičnega kitajskega pohištva ${ }^{2}$ sta plod širše percepcije kitajske kulturne dediščine, pri čemer prva temelji na dediščini romantično-eksotičnega pridiha chinoiserie, druga pa je plod splošnega akademskega diskurza in občudovanja kitajske učenjaške elite. Kategorija klasičnega kitajskega pohištva, ki je vezana na idealizacijo učenjaškega sloga dinastije Ming, je pravzaprav še bolj izključujoča. Vključuje namreč le pohištvo enostavnih linij s skladnimi proporci in minimalno dekoracijo, ki je bilo izdelano iz gostega trdega lesa, predvsem iz lesa huali 花梨. Ta je bil cenjen zaradi naravnih geometričnih vzorcev in oblik, pa tudi zaradi tega, ker je bil večinoma uvožen iz jugovzhodnih predelov Azije. Ta tip pohištva se večkrat pojavlja tudi pod imenom »pohištvo v stilu dinastije Ming« (Mingshi jiaju 明式家具), čeravno ne gre le

2 Že sama kategorija pohištva je pravzaprav izum zahodnih razprav, saj, kot ugotavlja Clunas (1988, 102), sodobni kitajski izraz za pohištvo jiaju 家具 (hišna/gospodinjska oprema) svoj pomen dobi relativno pozno. V dinastiji Ming in zgodnjem Qingu je ta izraz namreč označeval le kmetijske pripomočke, v kitajskem izrazoslovju pa so obstajali le tipi pohištva, kot so stoli in mize, ne pa pohištvo kot ločen termin. 
za primere iz te dinastije. Dejansko je večina danes ohranjenih kosov tega tipa nastala v zgodnjem obdobju dinastije Qing.

Teoretičen problem, ki se pojavi v tej polarizaciji, izhaja iz paradoksne (ne)povezanosti med materialnostjo in kulturnimi konotacijami. Težavnost umeščanja v določene kategorije pa nadalje temelji tudi na muzeoloških klasifikacijah in potrebi po razvrščanju v skladu z evolucijskim razvojem oblike oz. tehnike, geografskim poreklom ali kronološko sekvenco (Preziosi, 1996, 282). Muzeološke klasifikacije so pri tem rezultat epistemoloških paradigem sodobnega individuuma, ki konstruira znanje o zunanjem svetu glede na materialnost predmeta. Veda o klasifikacijah je gotovo nepogrešljiva za urejanje raznovrstnih materialnih podatkov, a gotovo ne izključno primarni korak v študijah zbirateljstva.

To se je še posebej pokazalo v določanju posamičnih konotacij kitajskemu pohištvu, ki temelji na dediščini kulturne percepcije v odnosu do materialne tradicije. Sprva skrivnosten in cenjen lak so zamenjale vrste trdega lesa, v zadnjih dveh desetletjih pa je tudi zaradi pomanjkanja tega materiala na umetnostnem trgu opazen porast interesa za mehak les ali celo bambus, in s tem preobrat na pozno obdobje dinastije Qing (Handler, 2001, 5). V okviru pohištva je k temu treba dodati predvsem material, dekoracijo in slog, ki so ključno vplivali na percepcijo kitajskega pohištva in s tem muzejske klasifikacije. Sprva romantična ideja evropsko globalnega sloga chinoiserie, ki je formirala idealizirano podobo kitajske kulture in družbe, se pod vplivom Bauhausove estetike minimalizma, nemškega ekspresionizma, ruskega konstruktivizma ter ostalih modernističnih umetniških gibanj transformira v idealizacijo enostavnih linij pohištva iz trdega lesa, ki preidejo v domeno elegantnosti in gracioznosti.

Skuškova zbirka pohištva je v tem kontekstu edinstvena. Ivan Skušek je gotovo eden izmed prvih zahodnih zbirateljev kitajskega pohištva, a v njegovi zbirki praktično ni ne bogato dekoriranega lakiranega pohištva niti klasičnega pohištva v stilu dinastije Ming. Nasprotno, v njegovi obsežni zbirki pohištva najdemo večinoma bogato rezljane lesene kose pohištva iz dinastije Qing in morebiti z začetka republikanske dobe na Kitajskem. ${ }^{3} \mathrm{Na}$ ta tip predmetov, ki je bil bolj ali manj odsoten v zahodnoevropski zbirateljski zgodovini, je pravzaprav opozoril šele Wang Shixiang leta 1988 s prvo monografijo o kitajskem pohištvu, ki jo je napisal kitajski strokovnjak, z naslovom Classic Chinese furniture: Ming and Early Qing dynasties, v naslednjih letih prevedeno tudi v tuje jezike. Craig Clunas v članku What is Chinese furniture ta tip pohištva izpostavi kot »razkritje celotnega tipa predmetov, ki jih zahod še ni videl« (Clunas, 1996, 16).

3 Za natančne datacije so potrebne nadaljnje raziskave, a omembe vredno je dejstvo, da se v Skuškovi zbirki pohištva nahaja tudi t. i. stranski stol, ki je skoraj identičen s stolom iz lesa huang huali, ki ga Wang Shixiang v svoji odmevni monografiji datira v dinastijo Ming (Wang, 1988, 79, slika 40). Vprašanje kasnejše rekonstrukcije oziroma predelave pusti odprto (Wang, 1988, 23), kar kaže na kompleksnost datiranja posameznih kosov pohištva tudi v luči dejstva, da so se standardizirale določene forme, ki so nato dominirale več stoletij. 
Clunas, ki je bil takrat kustos v muzeju V\&A, seveda ni mogel poznati Skuškove zbirke, saj je večina zahodnega diskurza dominirala na zahodnoevropskih in severnoameriških zbirateljskih praksah, torej nekdanjih evropskih imperialnih in kolonialnih centrih moči, druge zbirateljske prakse iz bolj perifernih območij pa so ostale v domeni spečih in skritih predmetov v muzejskih depojih. Ravno ta prisotnost povsem druge kategorije predmetov $\mathrm{v}$ evropskem perifernem prostoru pa prikaže izmenjavo predmetov v bolj kompleksni in večplastni časovni in prostorski konotaciji. Predvsem pa nedvomno postavi pod vprašaj koncept kitajskih predmetov odnosno pohištva ter izpostavi problematiko različnih nacionalnih percepcij in odnosa evropske periferije do nekdanjih imperialnih in kolonialnih sil, ki jasno razkrije, da produkcija vednosti in percepcija kitajske dediščine nastaja v veliko kompleksnejših pogojih in zato dobiva drugačne značilnosti.

\section{Skuškovo pionirsko odkrivanje elegantnih linij kitajskega pohištva}

Kako torej ovrednotiti Skuškovo vlogo v pionirskem odkrivanju elegantnih linij kitajskega pohištva v širšem kontekstu zbirateljskih strategij in kako se njegov odnos do kitajske dediščine odraža v tem kompleksnem kulturnem diskurzu? Nabor pohištvenih kosov v Skuškovi zbirki ponazarja, da niti evropska romantična percepcija lakiranega pohištva iz dediščine skoraj baročne chinoiserie niti minimalistični trendi v smeri funkcionalizma niso imeli večjega vpliva na oblikovanje Skuškove percepcije kitajske dediščine.

Za lažje razumevanje Skuškovega odnosa do kitajske dediščine in njegovega stika s Kitajsko si najprej poglejmo njegovo biografsko ozadje. Ivan Skušek je bil rojen leta 1877 v Metliki, majhnem kraju na jugovzhodnem delu današnje Slovenije. Z očetom, sicer cesarskim nadzornikom davčnih uradov na Kranjskem, se je večinoma selil po drugih manjših krajih (Postojna, Ribnica, Kočevje) znotraj kranjske regije, takrat ene izmed upravnih enot avstro-ogrske monarhije. Po šolanju na gimnaziji v Kočevju je odšel v Gradec, kjer je zaključil trgovsko akademijo in se nato pridružil avstro-ogrski cesarski kraljevi mornarici. Z vojnimi ladjami je plul po Sredozemlju ter se kasneje zaposlil kot uradnik na vojnem ministrstvu na Dunaju (Čeplak Mencin, 2012, 98). V Peking je prispel leta 1914, čisto po naključju, kot intendant na avstro-ogrski križarki S. M. S. »Kaiserin Elisabeth«. Ta se je po japonski vojni napovedi Nemčiji in Avstriji avgusta 1914 zasidrala pred mestom Qingdao na polotoku Shandong, kjer je pomagala braniti nemško koncesijo pred vojnimi napadi Japoncev. Po zmagi so Japonci zajete vojake odpeljali v japonska taborišča, nekatere mornarje, predvsem tiste, ki se niso bojevali, pa so zajeli Kitajci. Ivan Skušek je tako konec novembra 1914 pristal v Pekingu in ostal do leta 1920. Njegovo bivanje v Pekingu zaenkrat ostaja precejšnja neznanka, a glede na ohranjena pisma, ki mu jih je pošiljal nemški misijonar Kluge 
iz mesta Taiyuan v provinci Shanxi, je bil Skušek najverjetneje uradnik nizozemskega poslaništva (Kluge, 1919). Naslovi pisem razkrivajo, da je bival v nizozemskem delu diplomatskih četrti tujih poslaništev. ${ }^{4}$

Iz formalne izobrazbe ter ostale dokumentacije, ki izvira predvsem iz spominov Francija Skuška (1893-1989), ki je natančno zapisoval številne pogovore z bratom po povratku iz Pekinga, ni razvidno, da bi Skušek pred odhodom v tujino kakorkoli bolj podrobno prišel v stik s kitajsko kulturo, kakor je bilo to značilno za tujce, živeče v Pekingu v sicer kasnejših 30. letih. Lahko le sklepamo, da je kot uradnik na vojnem ministrstvu na Dunaju verjetno obiskoval umetnoobrtni muzej, ki se je nahajal tik poleg novozgrajene palače na Stubenringu, v katero se je leta 1913 preselilo vojno ministrstvo. Muzej je že leta 1907 prevzel večji del zbirke iz avstrijskega cesarskega in kraljevskega trgovskega muzeja, med katerimi so bili tudi predmeti iz Azije, hkrati pa je pridobil obsežno vzhodnoazijsko zbirko Heinricha von Siebolda (1852-1908), prevajalca in diplomatskega uslužbenca na avstro-ogrski ambasadi v Tokiu. Do kakšne mere so ti predmeti vplivali na Skuškovo percepcijo vzhodnoazijske kulture, težko ugotavljamo, a kot pomorščak je Skušek gotovo večkrat slišal o nenavadnih krajih z Daljnega vzhoda, pri čemer so bile te pripovedi veliko bolj naklonjene japonski vljudnosti in eleganci, Kitajcem pa so pripisovali surovost, nezaupljivost in odurnost v odnosu do tujcev (Šmitek, 1988, 414-415). Ivan Skušek sicer ni izhajal iz posebej premožne družine industrialcev, ki so iz tržno ekonomske dinamike večinoma krojili umetnostni trg, a kot prebivalcu petdeset milijonske države, ki se je raztezala na geografsko razgibanem prostoru raznolikega narodnostnega, verskega in jezikovnega ustroja, mu je Avstro-Ogrska gotovo nudila širino obzorja, predvsem pa ga je opremila z odprtostjo do sprejemanja različnih kultur in vrednot.

Iz tega vidika Skuškova preobrazba iz mornariškega komisarja v zbiratelja kitajske dediščine, ko se je konec novembra 1914 povsem naključno znašel sredi Pekinga, niti ni posebej presenetljiva. Znašel se je sicer sredi ravno najbolj živahnega trgovanja $\mathrm{z}$ umetninami, ki je bilo posledica politično turbulentnih dogajanj vse od opijskih vojn dalje. Sun Yat-senova revolucija leta 1911, ki je le tri leta pred prihodom Skuška v Peking spodnesla temelje tisočletni kitajski tradiciji, je še dodatno spodbudila dinamiko umetnostnega trga. Poleg novodobnih arheoloških izkopavanj, ki so zalagala starinarnice, je v težnji po preživetju svoje predmete in podedovano dediščino razprodajala tudi kitajska aristokratska elita. Na trgu so se med drugim znašle tudi dragocenosti iz številnih templjev, hkrati pa so iz palačnih predelov uhajali predmeti cesarskega porekla. Skušek sam poroča, kako so boksarji vdrli v Prepovedano mesto, oplenili precej palač, "pohištvo, kipe in druge težje predmete pa skrili po kleteh pri svojih zaupnikih " (Skušek, n.d.). To so nato prodajali samo tujcem in »nikakor ne kakemu Kitajcu, ker bi

4 Za transkribiranje in prevode nemških pisem, ki jih je Skušku v Peking pošiljal misijonar Kluge, se zahvaljujem Niku Hudelji z Oddelka za zgodovino na Filozofski fakulteti. 
se to lahko zvedelo in bi lahko izgubili glavo« (Skušek, n.d.). Ne samo boksarji, predvsem tudi zavezniške sile, ki so okupirale Peking v letih 1900-1901, da bi zaščitile svoja poslaništva pred kitajskim obleganjem, so pospešile razpršitev kitajskih predmetov iz cesarskih in prinčevskih palač. Vse to dogajanje je preplavilo pekinške ulice s številnimi neprecenljivimi predmeti iz različnih zgodovinskih obdobij.

To dinamično dogajanje na področju umetnostnega trga je nedvomno naredilo vtis tudi na avstro-ogrskega mornarja slovenske narodnosti.

Nebroj trgovin je prodajalo razne stare predmete, knjige, poslikane pahljače, pohištvo, slike, vaze, bogove iz porcelana in druge umetnine, kipe iz brona, oblačila, lestence stoječe ali viseče iz medenine ali iz umetniško izrezanega trdega lesa. (Skušek, n.d.)

Raznolikost predmetov se odraža tudi v Skuškovi zbirateljski vnemi, ko je zagnano kupoval najrazličnejše predmete, pri tem pa skladno $\mathrm{z}$ natančnostjo knjigovodja ${ }^{5}$ delal podroben seznam vseh nakupljenih predmetov z navedbo zneska v kitajskih dolarjih (Skušek, n.d.). Njegova zbirka kaže na poseben interes prav za arhitekturo in pohištvo, pri tem pa so ga estetsko privlačile elegantno čiste linije, dopolnjene $z$ bogato rezljano motiviko, ki prikazuje kitajske tradicionalne motive v obliki zmajev, levov, različnih ptic, cvetja, nesmrtnike ter ostale simbole, ki prinašajo srečo, zadovoljstvo, bogastvo in dolgoživost (sliki 3 in 4).V Skuškovi kolekciji pohištva so praktično zbrani prav vsi tipi pohištva, ki jih v 80. letih klasificira poznavalec kitajskega pohištva Wang Shixiang (1988). Njegova zbirka hkrati vključuje tudi okrasne stene, ki so delile notranjost kitajskih prostorov, ter model kitajske hiše, po katerem naj bi zgradili muzej. Skuškov interes za notranjo opremo v povezavi z arhitekturno konstrukcijo pa nadalje odražajo tudi trije zvezki profesionalnih fotografij in natančnih arhitekturnih analiz Prepovedanega mesta, ki jih izdala Tokijska cesarska univerza leta 1906.

V nasprotju s Katesom, ki se poistoveti z idealizirano podobo kitajskega učenjaka iz dinastije Ming, ko v preprosto opremljenem interierju ležerno preživlja prosti čas, je Skuška pri nakupu in zbiranju različnih kosov pohištva poleg dostopnosti predmetov na trgu gnala prav težnja po ustanovitvi muzeja v Ljubljani. S tem bi bogastvo kitajske dediščine predstavil tudi rojakom doma, »Tzu [njegova žena] v japonskem kimonu pa bi sprejemala obiskovalce in jim, ako njega ne bi bilo doma, tudi razlagala poreklo in starost razstavljenih predmetov« (Skušek, n.d.). Muzej si je zamislil v stilu kitajske tradicionalne arhitekture, za te potrebe pa domov pripeljal celo model kitajske hiše, ki danes velja za enega redkih ohranjenih primerov.

5 Ivan Skušek je bil mornariški komisar 1. ranga, na ladji je vodil knjige in račune ter deloval v funkciji blagajnika in ekonoma. 


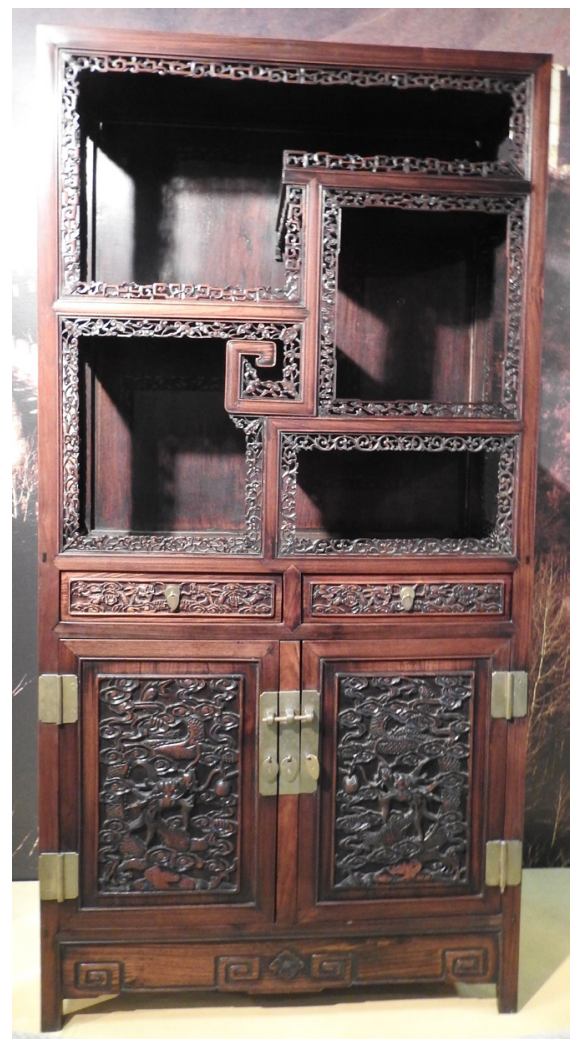

Slika 3: Vitrina, rezljan les, dinastija

Qing, Kitajska, Skuškova zbirka

(foto: Slovenski etnografski muzej).

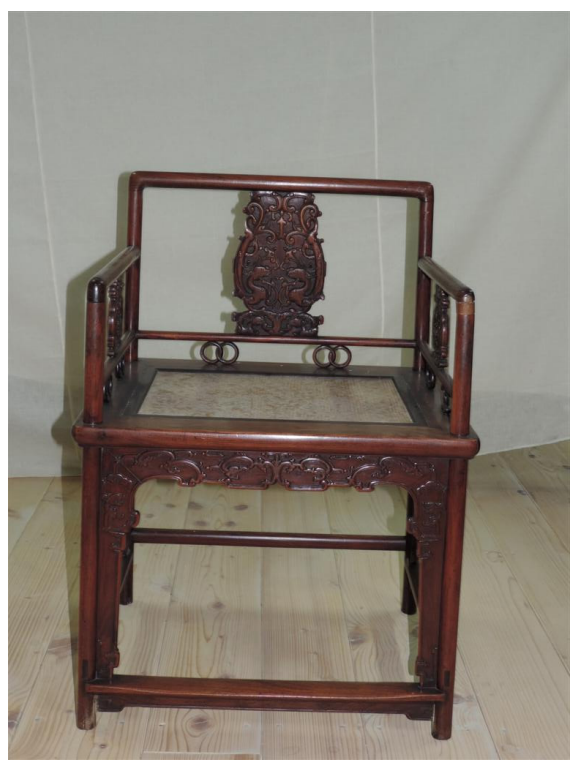

Slika 4: Stol, rezljan les, dinastija Qing, Kitajska, Skuškova zbirka (foto: Slovenski etnografski muzej).

Poleg dostopnosti na trgu in cenovno ugodnih predmetov pa gre pri Skuškovem naboru predmetov verjetno predvsem za intuitivni nabor, podvržen estetskemu okusu. Do kakšne mere je na izbor predmetov vplivala njegova mlada žena Japonka Tsuneko Kondō Kawase (1893-1936), ki jo je spoznal v Pekingu, težko ugotavljamo, a veliko vlogo je pri naboru verjetno odigral prav Skuškov poglobljen stik s kitajsko družbo in kulturo. Ta težnja se do neke mere odraža tudi v motiviki bogato rezljanega pohištva, ki je vezana na kitajsko tradicijo. Okus si je gotovo ostril tudi v pogovorih z drugimi poznavalci in ljubitelji kitajskih predmetov. Iz zapisov Francija Skuška, v katerih trdi, da je Ivan poznal celo angleškega učitelja zadnjega cesarja mandžurske vladavine Reginalda Fleminga Johnstona (1874-1938) (Skušek, n.d.), lahko sklepamo, da se je gibal v višjih krogih zahodnjaške elite. Stik z nemškim ljubiteljskim arheologom Klugetom, ki je na Kitajskem deloval v okviru misijonarskih poslov, pa razkrivajo ohranjena pisma, ki jih hrani Slovenski etnografski muzej. 


\section{Skuškova percepcija kitajske kulturne dediščine}

$\mathrm{V}$ analizi Skuškove zbirke kitajskega pohištva in ostalih predmetov je opazen Skuškov celovit pristop do razumevanja kitajske kulturne dediščine. Zbirka enciklopedične narave zajema praktično vse različne tipe predmetov, ki so se takrat znašli na trgu umetnin. Zelo verjetno je načrtoval postavitev predmetov $v$ avtentičnem notranjem ambientu premožnejše elite, kar potrjuje tudi nakup okrasnih sten, ki so krasile kitajske sobane. Muzeja v stilu kitajske tradicionalne arhitekture zaradi finančnega primanjkljaja sicer ni uspel zgraditi, a fotografije njegovega stanovanja zgovorno pričajo, da si je uredil stanovanje v kitajskem slogu (slika 5).

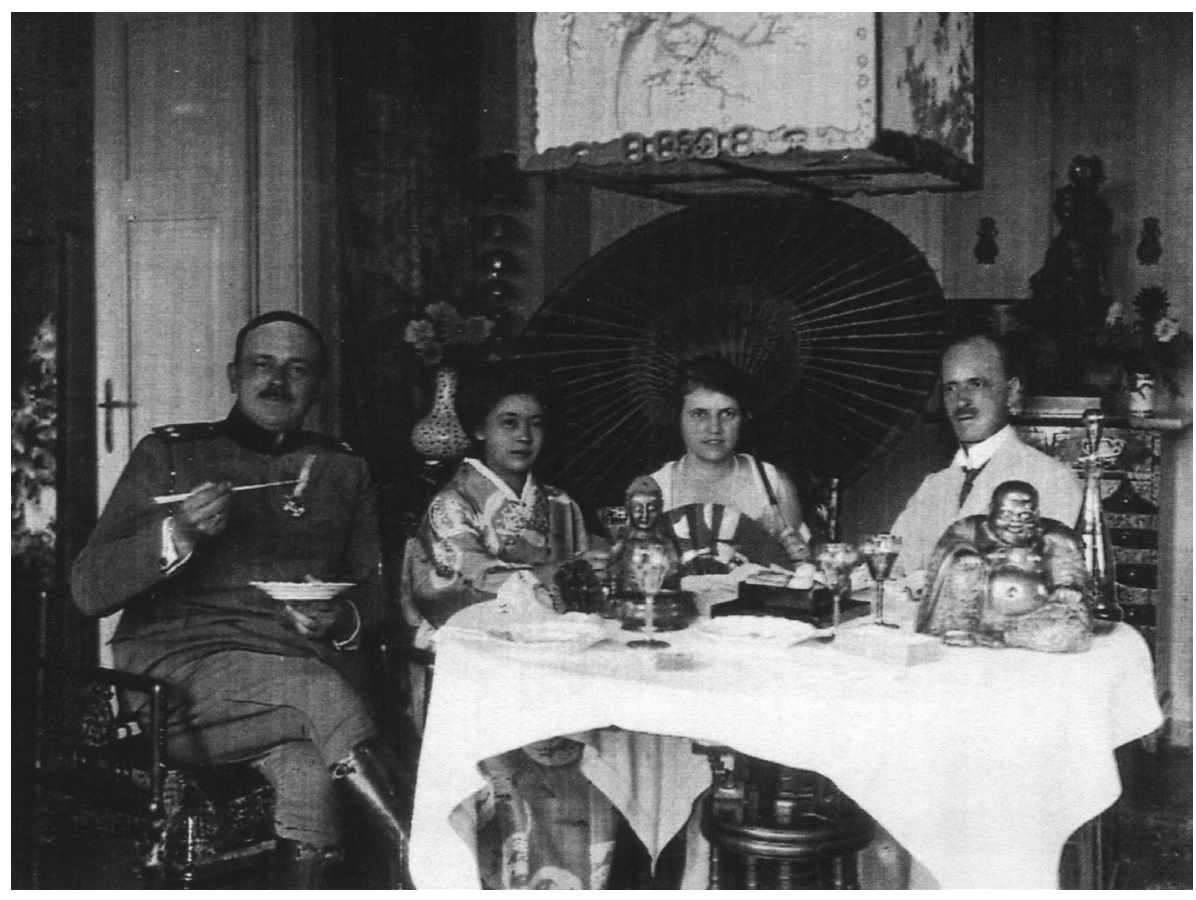

Slika 5: Ivan Skušek v stanovanju (od leve proti desni: polkovnik Dimitrijević, Marija Skušek, žena polkovnika Dimitrijevića, Ivan Skušek) (vir: Janez Lombergar).

Iz tega sledi, da Skuškov odnos do kitajske kulturne dediščine ni bil vezan le na materialno percepcijo vrednih umetniških predmetov, temveč je s celostnim pristopom in umestitvijo pohištvenih kosov v lastno stanovanje legitimiral kitajsko družbeno-kulturno okolje kot enakovredno zahodni civilizaciji in vsem dosežkom. Iz bratovih zapisov je razvidno, da je Skuškova retorika v odnosu do kitajske kulture drugačna od ostalih posameznikov, ki so v zgodnjem 20. stoletju prišli v stik s Kitajsko. Z veliko večjo naklonjenostjo je govoril o domačinih, Kitajci so bili po njegovem mnenju 
"pridni, delavni, inteligentni, dobrodušni, varčni, vljudni in gostoljubni« (Skušek, n.d.). Njegov odnos do Kitajcev in njihove kulture je bil bistveno drugačen kot pri večini ostalih Evropejcev, ki so predvsem slavili japonsko vljudnost in njihov hiter napredek. Zahodnoevropski, predvsem francoski aristokratski zbiratelji so bili na primer tako zgroženi nad fizičnimi razmerami in življenjskim stilom na Kitajskem, da so cenili izključno materialno kulturo. Za znana francoska zbiratelja brata Goncourt je bila vrednost »kitajskih predmetov« izključno v domeni materialnosti in njihove ločenosti od družbenega ozadja izvora produkcije (Chang, 2011). Tudi po mnenju Théodora Dureta (1838-1927), ki se je skupaj z zbirateljem azijske umetnosti Henrijem Cernuschijem (1821-1896) leta 1871 odpravil na potovanje v Vzhodno Azijo, je bila materialna kultura Kitajske edini omembe vreden dosežek kitajske nacije (Chang, 2002, 26).

Nasprotno Skuškov odnos do kitajske kulturne dediščine ni bil plod evrocentrične kulturne imaginacije o Kitajski, v okviru katere je bilo cenjeno vse, kar je bilo izdelano v času pred mandžurskim cesarjem Qianlongom (vlada 1736-95), vsi kasnejši produkti pa so postali simbol degradirane kitajske kulture. V skoraj šestletnem bivanju v Pekingu je očitno dodobra spoznal kitajske navade in različne običaje ter prihajal v bolj intenziven stik $\mathrm{z}$ domačini, ki jih je cenil kot izjemno delavne in inteligentne. $\mathrm{V}$ tem kontekstu je treba tudi razumeti njegov celostni pristop k zbiranju kitajskih predmetov, in ne le preferenčnih tipov predmetov, ki jih je določala zahodnoevropska tržna dinamika preprodajalca-kupca. Njegov ambiciozen načrt postavitve replike premožne kitajske hiše z vso notranjo opremo pa je med drugim dodatno prispeval k temu, da je že v tem času uspel prepoznati pomen umetniškega produkta v lesenih kosih pohištva. Bolj kot porcelanasti kosi posodja so ga zanimali predmeti, ki so odražali fizični stik s kitajskim prostorom, družbo in kulturo. Ravno pohištvo in arhitekturni elementi pa so tisti vidik materialne kulture, ki vzpostavi interaktivno okolje in stalen fizični stik, s tem pa na nek način omogočijo vzdrževanje celotnega kulturnega ozadja kitajske družbe v drugem okolju.

Večji centri v zahodnoevropski in severnoameriški regiji so bili nasprotno še vedno pod vplivom eksotičnega laka in visoke materialne preference. Preferenca za lakirano pohištvo je med drugim vidna tudi v Skuškovi težnji prodaje bogato rezljanega okvirja za ogledalo z dvema manjšima levoma. Iz več ohranjenih osnutkov pisem je razvidno, da je različnim institucijam na zahodu želel prodati omenjena lesena okvirja za ogledalo (Skušek, 1926). Kustosa oziroma posebnega odbora zaupnikov ravno ustanovljene Umetnostne galerije Lady Lever v Angliji pa očitno ni prepričala niti povezava okvirja s cesarskim izvorom. Skušek je namreč prejel le skromen odgovor, datiran s 3. 9. 1925, da jih predmeta ne zanimata (Davison, 1925). Skuškove estetske smernice tako niso naletele na odprta ušesa, zanimanje za leseno, sicer minimalistično dekorativno pohištvo, ki je nadomestilo prejšnje poudarke na lakiranem pohištvu, pa se je vzpostavilo šele v povojnem obdobju. 


\section{Sklep}

Skuškov nabor predmetov torej ni bil podvržen kulturnemu diskurzu evrocentrične imaginacije o Kitajski, niti ne zahodnoevropski tržni dinamiki preprodajalca-kupca, ki je bila v prvi meri omejena na porcelan, lak in kovinske izdelke. Skušek tudi ni prejel močnejšega impulza s strani poznavalcev kitajske kulture, ki bi ga posebej navdušili nad Kitajsko, kot je bilo na primer za Katesa srečanje s slavnim sinologom Pelliotom. Nikakor se tudi ni mogel primerjati s samozavestnimi Angleži, Francozi ali Nizozemci, ki so se ponašali $\mathrm{z}$ večstoletno trgovsko in politično povezavo z Vzhodno Azijo avstro-ogrska monarhija se je namreč podala v boj za azijsko tržišče precej pozno, šele v 19. stoletju po odprtju Sueškega prekopa.

Skuškova percepcija kitajske dediščine je bila tako formirana na lastnih izkušnjah in po stiku s kitajsko družbo v začetku 20. stoletja, večjo dovzetnost in zanimanje za tuje kulture in navade pa mu je omogočilo multinacionalno okolje avstro-ogrske monarhije. Prav to dvoje je tisto, kar je omogočilo, da je Ivan Skušek kot eden izmed prvih na zahodu prepoznal pomen elegantnih in bogato okrašenih kosov lesenega pohištva in jim pridal status umetniškega predmeta, ki je vreden zbirateljske vneme. Predvsem pa jim je pridal status predmeta, ki ni ločen od geokulturnega ozadja Kitajske, temveč razločno poudarja kitajski izvor in posledično legitimira kitajsko kulturno dediščino. Z izgradnjo muzeja $\mathrm{v}$ avtentičnem slogu aristokratske kitajske hiše $\mathrm{z}$ vso notranjo opremo kot celostne umetnine bi svoje spoštovanje do kitajske kulture še jasneje manifestiral. Skuškova definicija kitajskih umetniških izdelkov torej ni bila omejena le na »odtujeno« materialno dediščino iz kitajskega konteksta, temveč je bila umeščena v širše razumevanje družbeno-kulturnega okvira. Na nek način je postavljal temelje tudi v tem smislu, okvire za to pa sta mu omogočila prav periferni položaj slovenskega etničnega prostora ter multikulturnost avstro-ogrske monarhije.

\section{Zahvala}

Prispevek je nastal v okviru projekta Vzhodnoazijske zbirke v Sloveniji: vpetost slovenskega prostora v globalno izmenjavo predmetov in idej z Vzhodno Azijo (2018-2021) (št. J7-9429) in programske skupine Azijski jeziki in kulture (št. P6-0243), ki ju iz državnega proračuna financira Javna agencija za raziskovalno dejavnost Republike Slovenije. Posebna zahvala gre kustosu Ralfu Čeplaku Mencinu iz Slovenskega etnografskega muzeja za dostop do vsega gradiva. Zahvaljujem se tudi Janezu Lombergarju za dovoljenje za objavo fotografije Skuškovega stanovanja in anonimnemu recenzentu za vse konstruktivne komentarje. 


\section{Bibliografija}

Chang, T., Collecting Asia: Théodore Duret's "Voyage en Asie" and Henri Cernuschi's Museum, Oxford Art Journal, Vol. 25, No. 1, 2002, str. 19-34.

Chang, T., Goncourt's China cabinet: China fantasy and a nineteenth-century French collector, v Collecting China: The world, China, and a history of collecting (ur. Rujivacharakul, V.), Newark 2011, str. 31-45.

Clunas, C., Chinese furniture, London 1988.

Clunas, C., What is Chinese furniture? The changing Western image of Chinese furniture, v Chinese Furniture: Selected articles from orientations 1984-1994, Hong Kong 1996, str. 16-25.

Čeplak Mencin, R., V deželi nebesnega zmaja. 350 let stikov s Kitajsko. Ljubljana 2012.

Davison, S. L., Pismo kustosa iz Umetnostne galerije Lady Lever, Slovenski etnografski muzej, 3. 9. 1925 , neobj.

Ecke G., Chinese domestic furniture in photograps and measured drawings, ponovni tisk, original Peking 1944.

Ferguson, J. C., Survey of Chinese art. Shanghai 1940.

Handler, S., Austere luminosity of Chinese classical furniture, Berkeley, Los Angeles, London 2001.

Kates, G. N., Chinese household furniture, New York 1948.

Kluge, P. M., Pismo Skušku, Taiyuan 20. 2. 1919. neobj.

Mason Jr., L. E., Examples of Ming furniture in American collections formed prior to 1980, Orientations, Vol. 23, No.1, 1992, str. 74-81.

Motoh, H., "The master said:"-- Confucius as a quote, Asian Studies, Vol. 7, No. 2, 2019, str. 287-300.

Preziosi, D., Collecting/Museum, v Critical Terms of Art History (ur. Nelson, R. in Stiff. R.), Chicago 1996.

Skušek, F., Rokopisni zapiski Francija Skuška. Ljubljana, n.d.

Skušek, I., Pismo Muzeju umetnosti Mineapolis, Ljubljana 3. 5. 1926, neobj.

Šmitek, Z., Poti do obzorja: antologija slovenskega potopisa z neevropsko tematiko, Ljubljana 1988. Wang, S., Classic Chinese furniture: Ming and Early Qing dynasties, Hong Kong 1988.

\section{Nataša Vampeli Suhadolnik}

\section{Ivan Skušek ml. kot zbiratelj kitajskega pohištva}

Ključne besede: Ivan Skušek ml., zbirateljstvo, kitajsko leseno pohištvo, lakirano pohištvo, klasično kitajsko pohištvo

Članek prikaže zbirateljsko strategijo Ivana Skuška ml. (1877-1947), pri čemer pod drobnogled postavi kitajsko pohištvo. Analiza zbirateljstva kitajskega pohištva v širšem evropskem kontekstu je pokazala, da lahko Ivana Skuška umestimo med prve zahodne zbiratelje, ki so v posameznih kosih kitajskega lesenega pohištva že v drugem desetletju 20. stoletja prepoznali umetniško obliko. Leseno pohištvo je namreč večjo mednarodno pozornost doseglo šele v 40. in 50. letih 20. stoletja, ko so začele izhajati prve angleške publikacije. 
Pri analizi Skuškove vloge v kontekstu zbirateljstva kitajskega pohištva izhajamo iz širše perspektive zbirateljstva v evro-ameriškem prostoru in kulturne klasifikacije, ki je na piedestal večinoma umeščala predmete iz porcelana in laka. Skuškovo vlogo nadalje poskušamo umestiti v širši evropski diskurz zbirateljskih strategij pohištva, pri tem pa se dotaknemo tudi vprašanja definicije kitajske dediščine, kar nadalje izpostavi problematiko kulturnega diskurza evrocentrične imaginacije o Kitajski in s tem različne nacionalne percepcije.

\section{Nataša Vampeli Suhadolnik}

\section{Ivan Skušek Jr. as Collector of Chinese Furniture}

Keywords: Ivan Skušek Jr., collecting, Chinese wooden furniture, lacquer furniture, Chinese classical furniture

The paper discusses the collecting strategy of Ivan Skušek Jr. (1877-1947) with a focus on Chinese furniture. The analysis of collecting Chinese furniture in a broader European context reveals that we can consider Ivan Skušek as one of the first Western collectors who in the second decade of the $20^{\text {th }}$ century already recognized the artistic value of individual domestic Chinese furniture pieces. In contrast, international appreciation of Chinese hardwood furniture only emerged in the 1940s and '50s after the first English-language publications had appeared.

Skušek's role in collecting Chinese furniture is therefore analysed on the basis of the broader context of the collecting history in the Euro-American region and the cultural classification, which held objects made of porcelain and lacquer in high esteem. In addition, the author attempts to place Skušek's role within the European discourse of furniture collecting strategies, touching also on the definition of Chinese heritage, which further highlights the question of the cultural discourse of the Eurocentric imagination about China and thus the different national perceptions of Chinese heritage.

\section{O avtorici}

Nataša Vampelj Suhadolnik je izredna profesorica na Oddelku za azijske študije na FF UL. V svojem raziskovalnem delu se ukvarja z materialno in zbirateljsko kulturo, vzhodnoazijsko dediščino v slovenskem prostoru, kitajsko tradicionalno in moderno umetnostjo, kitajsko grobno umetnostjo ter kitajsko budistično umetnostjo. Je soustanoviteljica in prva predsednica Evropske zveze za azijsko umetnost in arheologijo (EAAA), vodja nacionalnega projekta Vzhodnoazijske zbirke v Sloveniji (2018-2021) ter raziskovalne skupine na FF UL v okviru mednarodnega projekta Pagode (2020-2021). Je avtorica monografije V svetu nesmrtnih bitij: grobna umetnost dinastije Han in njena kozmološka zasnova (2017), več poglavij v monografskih publikacijah ter vrste znanstvenih člankov. 


\section{About the author}

Nataša Vampelj Suhadolnik is Associate Professor at the Department of Asian Studies of the Faculty of Arts, University of Ljubljana. Her research fields include material culture, collecting history, East Asian cultural heritage in Slovenia, Chinese art and archaeology. She is the president of the European Association for Asian Art and Archaeology (EAAA). She is also the leader of the national project East Asian Collections in Slovenia (2018-2021) and one of group leaders within the international project PAGODE-Europeana China. She is also the author of the monograph In the World of Immortal Creatures: Grave Art of the Han Dynasty and its Cosmological Design (2017), several chapters in monographs and a series of scientific papers. 